\title{
Managing the Energy Transition through Discourse. The Case of Poland
}

\author{
Joanna Krzywda ${ }^{1, *}$, Dariusz Krzywda ${ }^{1}$ and Armenia Androniceanu ${ }^{2,3}$ (D) \\ 1 Faculty of Management, Czestochowa University of Technology, Dabrowskiego 69, \\ 42-201 Czestochowa, Poland; dariusz.krzywda@pcz.pl \\ 2 Faculty of Administration and Public Management, Bucharest University of Economic Studies, 9, \\ Piata Romana, 010374 Bucharest, Romania; armenia.androniceanu@man.ase.ro \\ 3 Research Department, University of Social Sciences, Sienkiewicza 9, 90-113 Lodz, Poland \\ * Correspondence: joanna.krzywda@pcz.pl
}

Citation: Krzywda, J.; Krzywda, D.; Androniceanu, A. Managing the Energy Transition through Discourse. The Case of Poland. Energies 2021, 14, 6471. https://doi.org/10.3390/ en14206471

Academic Editors: Beata Ślusarczyk, József H.c. Popp and Judit Oláh

Received: 15 September 2021

Accepted: 4 October 2021

Published: 10 October 2021

Publisher's Note: MDPI stays neutral with regard to jurisdictional claims in published maps and institutional affiliations.

Copyright: (c) 2021 by the authors. Licensee MDPI, Basel, Switzerland. This article is an open access article distributed under the terms and conditions of the Creative Commons Attribution (CC BY) license (https:// creativecommons.org/licenses/by/ $4.0 /)$.

\begin{abstract}
Since energy transition has become a necessity, many countries are developing decarbonization plans and looking for ways to reduce $\mathrm{CO}_{2}$ emissions. The process takes different forms, most often being affected by local conditions, which means that it takes place in each country differently, due to the country's social and economic specifics. One of the countries that has just started its energy transition process is Poland. The case of Poland is extremely interesting, as it is a country whose economy is still heavily dependent on coal and there are very strong traditions related to this particular source of energy. On the other hand, Poland has two very good reasons to move away from coal. The complexity and comprehensiveness of the energy transition results, among other things, from the diversity of actors involved in this issue and the multiplicity of their, often conflicting, interests. Using a critical discourse analysis, this paper attempts to show how those actors attempt to shape the transition through the discourses which they generate. The study covers the media discourse that took place in Poland between September 2020 and May 2021, i.e., a time when the Polish government negotiated with representatives of the miners' trade unions the terms of Poland's transition from coal. A critical analysis of the texts that appeared in the media during this time provides a picture of how different groups of social actors perceive the transition and how they try to manage that process.
\end{abstract}

Keywords: energy transition; decarbonization; coal phase-out in Poland; managing the energy transition; critical discourse analysis

\section{Introduction}

With climate change becoming increasingly evident in recent years, many countries have become convinced of the need to reduce $\mathrm{CO}_{2}$ emissions [1]. The Paris Agreement in 2015 set out a global action plan to save the planet from the threat of far-reaching climate change. Since the major culprit contributing to warming is fossil fuels, it became imperative to stop using them. Thus, many countries faced the prospect of switching from coal to alternative sources of energy, mainly renewable energy, and this process became known as energy transition. Although a name has been adopted for this process, the expression 'energy transition' is a blurry and ambiguous concept and its final outcome is not defined [2]. The implementation of energy transition itself is also taking place or will take place with different dynamics, depending on local circumstances. Energy transition studies, which already have a considerable tradition, involve different aspects, ranging from historical approaches through economic and technical approaches to organizational and political aspects. In order to understand the nature of the energy transition, it is certainly necessary to conduct case studies in individual countries, which can help to assess the advancement of the transition from coal and try to answer the question of how to manage the energy transition process. 
One of the countries that are at the beginning of decarbonization is Poland. The case of Poland is extremely interesting because it is a country whose economy still heavily relies on coal and there are very strong traditions associated with this energy source. On the other hand, Poland has two very good reasons to move away from coal. Firstly, the situation of the Polish mining industry, and secondly, the requirements made by the European Union, of which Poland is a member. On the other hand, it is also about the future of the mining regions and national energy security. Therefore, the energy transformation in Poland must take place, but the question is how to manage it.

The first steps in this direction have already been taken. At the turn of 2020/2021, for the first time a date was set for Poland's transition from coal, which is to take place in year 2049. As a result, a social contract was signed, setting out a timeframe for Poland's transition away from coal and for providing miners with welfare assistance. The negotiations took several months, and together with the final contract reached, they represent a very important moment in Poland's energy transition, creating a kind of roadmap that Poland will (perhaps) follow in the years to come. In the period from September 2020 to the end of May 2021, i.e., during the negotiations, their participants (miners' trade unions and government representatives) as well as other public actors participated in the media discourse on Poland's transition from coal. Each of these groups represents a slightly different vision of the energy transformation process and tries to manage it by creating their own discourse. These discourses focus, as if in a lens, on the motives and concepts, as well as disruptions and barriers of Poland's energy transition. The aim of this study is to analyse these discourses and then define the nature of the energy transition in Poland, at what stage it is, and how its main actors choose to manage it.

\section{Literature Review}

Literature on energy transition is remarkably rich and comprehensive. Energy transition is seen as a kind of socio-technological transition, on which research already has its own tradition, being part of the so-called transition studies [3]. In these studies, it is assumed that all transitions follow similar principles and are guided by the same mechanisms. Thus, for example, transformations in agriculture [4], wastewater infrastructure [5], transportation [6,7] or food [8-10] are investigated and can be conceptualized in the same way. Such transitions are also sometimes called sustainability transitions and involve changes in socio-technical systems. Socio-technical systems consist of networks of actors, (individuals, firms and other organizations, collective actors) and institutions (societal and technical norms, regulations, standards, etc.) as well as material artifacts and knowledge that provide certain services for society. Transformations which occur within these systems are called socio-technical transitions, and they are a set of processes that lead to a fundamental shift in the system [11].

Research on socio-technical transition has also been applied to energy issues [12]. Several approaches have been identified in the literature on energy transition. At first, many works thematized the characteristics of historical transitions. Recently, this research area has begun to expand, becoming a field of study for many disciplines such as economics, sociology, psychology, political science, management, engineering, geography and philosophy [13]. More practical approaches such as modelling have also been developed [14].

All of these studies seek answers to questions about the nature of energy transition. Energy transition, as a type of socio-technological transition is a multi-dimensional, complex, non-linear, non-deterministic, and uncertain process difficult to characterize $[15,16]$. Energy transition is impossible without new technological solutions, yet it is considered by many to be primarily a shift from an economic system dependent on specific energy sources and technologies to a different economic system [16]. Due to its connection to the economic system, however, it can be assumed that energy transition takes on different dynamics and characteristics depending on the country. Hence, studies on energy transition in different countries are conducted from different perspectives and address different specific challenges of energy transition, e.g., in Denmark [17], France [18], Switzerland [19], 
Germany [20], and UK [15,21]; however, there are also comparative studies conducted, e.g., [22-24].

Very important in research on energy transition is the set of tools with which the essence of this phenomenon can be investigated. The most well-known and providing the greatest perspective here is the multi-level perspective of socio-technical transition (MLP) created by Geels $[25,26]$. According to this approach, socio-technical systems do not function on their own, but are actively created and maintained by human actors embedded in social groups. Geels developed a special terminology that has become well-established in transition studies. It refers to socio-technical landscapes, regimes and niches. The sociotechnical landscape relates to material and immaterial elements at the macro level: material infrastructures, political culture and coalitions, social values, worldviews and paradigms, the macro economy, demography, and the natural environment. The second level, that of regime (meso level), relates to dominant practices, rules and shared assumptions. At this level are the interests, rules and beliefs that guide private action and public policy, for the most part geared towards optimising rather than transforming systems. The niche level (micro level) relates to individual actors and technologies, and local practices. At this level, variations to and deviations from the status quo can occur, such as new techniques, alternative technologies and social practices [27]. Very many transitions occur in the same way, i.e., there is interaction between levels. In niches, impulses are created that reach the other levels in the form of novelties. At first, the regime stops the impulses coming from niches. Later, however, once a novelty comes into its own, the regime can have an enabling role, through the application of large amounts of capital. Thus understood, MLP is the most important method for analysing all transitions, including energy transitions. Although there are, e.g., its extensions, such as the transition model canvas (TMC) method, proposed by Rijnsoever and Leendertse [28] and the MLP has sometimes been criticized, and transition studies' methodology is underdeveloped [13], it is the most important element in the body of research on energy transitions. Next, this study aims to verify the research hypothesis that some of the energy transition discourses present in Poland are dominant, that there are visible tensions between the actors in the transition process, and that the coal regime's discourse is particularly powerful, which is likely to prove a significant obstacle to the successful energy transition.

\section{Conceptual Framework and Methodology}

The study presented below uses elements of MLP and critical discourse analysis (CDA) complemented with the concept of critical moments. A critical moment is a particular time and place where different discourses clash with each other. As a result of these clashes, some of them are challenged and consequently dislocated or unhinged, which, potentially, allows for the shift to a new order of discourse [29,30]. This is a situation typical of conflicts, and these in turn are inevitable in transitions [30]. CDA, on the other hand, is one of the methods that due to the nature of socio-technical transition is used in transition studies [13]. This is how, for example, regime dynamics in the Dutch energy transition [31], the introduction of digital ride-sharing platforms in Indonesia [30], discourses as one of the forms of power [32], solar transition in the U.S. [33], the history of American railroads [34] and others have been studied [35,36]. The use of CDA in the study of socio-technological transitions is primarily supported by the nature of the research objective. Indeed, due to its complexity and comprehensiveness, transitions studies cannot be reduced to statistical models commonly used in management and marketing sciences, so qualitative methods are recommended here [37], and CDA is one of these methods.

Critical discourse analysis, first proposed by Fairclough [38] is an approach which has gained considerable acceptance and popularity since the early 1990s. CDA is now applied to the analysis of many problems, including those in the social sciences where there is talk of a 'linguistic turn'. It is also an approach that can be used in the management sciences [39]. At the centre of CDA is, of course, discourse, the definition of which has been the subject of numerous papers. Here it is assumed that "discourse is text and talk in 
context, analysed with a focus on the social functions it performs" [39], or in other words "language in use". Discourse theory holds that social reality is produced and made real through discourses, and social interactions cannot be fully understood without reference to the discourses that provide them meaning [40]. It is assumed that critical discourse analysis is not actually a research method, but rather a group of approaches that are constituted at different levels [41]. CDA assumes that language constructs the social world and is simultaneously constructed by it. Discourse is intrinsic to the social world and is a causal force in social constructions; it is essential for explaining the social world [42]. CDA emphasizes the social context of language in use and its relationship to social reality. Discourse is an element of social life dialectically related to other elements of social life and can have a constructive and transformative effect on them. Fairclough [43] argues that an increasing number of significant current social transformations are initiated and caused by changes in discourse. Because of its methodological and interdisciplinary openness, CDA is highly suited to the analysis of multimodal and complex phenomena and can be applied to a variety of heterogeneous research areas [43].

Underlying the theoretical basis of this study is the aforementioned assumption that energy transitions are country-specific and have their characteristic hurdles and drivers. This statement is firstly of a scientific nature and is confirmed by many studies on the specifics of country-specific transformations. Secondly, this fact can be observed in practice, as many countries develop their own decarbonisation pathways and publish documents and legislation in which they define their own ways and dates of decarbonisation. Following Brauers et. al. it is assumed that policy outcomes regarding coal consumption are deeply influenced by several actor groups, such as trade unions, environmental organizations and the government [24]. An analysis of the situation in various countries shows how these forces interact with the coal regime. In the UK, miners' opposition to mine closures was suppressed as early as the 1980s, although not for climatic reasons but for political reasons. In Germany, trade unions and influential coal companies slowed the decline of coal. The main objective here became the creation of employment opportunities [24]. In terms of the economic and social role of coal, Poland can be compared to Britain and Germany, which are also coal powers.

Poland's transition will be a difficult process from a social point of view, as there are particular perceptions of coal in Poland. Coal is seen here as the foundation of the country's place in the world. On the other hand, coal is beginning to be associated with the debt and restructuring of the Polish mining industry and public opposition to new mines [44]. Polish miners are in an extremely difficult situation when looking for a new job because of their relatively low education and high age [45]. The discussion about coal in Poland is not a politically neutral discussion, and the defence of the coal regime has become part of the strategy of the current government $[46,47]$. There are also studies that point to the expected difficulties for Poland in pursuing an energy policy aimed at reducing $\mathrm{CO}_{2}$ emissions, because although the public accepts the $\mathrm{CO}_{2}$ reduction policy, they may object to it if it also leads to increased unemployment and energy prices [48]. The main actors of the transition in Poland, i.e., the government, the energy sector and local actors, are perceived as not transparent and dishonest [49].All these statements form a theory according to which the transformation from Poland can be expected to proceed with difficulty and slowly.

Energy transformation in Poland is a complex and complicated phenomenon. Any transformation has its social actors, institutions that create their story lines and undergoes its critical moments. This study assumes that each of the groups involved in the energy transition in Poland are trying to manage the transition in such a way as to achieve their goals and they are doing so with the help of the discourse they create. By choosing linguistic means in media statements, each group handles the transformation process by creating an image of the transformation itself, its other actors and themselves in a certain way in order to influence how this very group is subsequently perceived. The essence of the CDA research is to reveal hidden meanings in texts and how power, understood as influence, is realized through language, and then to reconstruct the knowledge created by 
discourse. In order to adequately interpret the texts within the framework of CDA, in the first part of the study, referring to the MLP methodology, the most important facts from the history of Polish mining are recalled and its current situation is outlined. Against this background, the events of the most recent critical moment in the transformation, i.e., the Polish government's negotiation of the contract with the miners on closing the mines, are presented. Such outline provides a context for the discourse that took place in Poland from September 2020 to May 2021 and enables an appropriate interpretation of the texts.

The analysis was based on the approach used by Wodak [50] and Kopinska [51], and carried out with the use of MAXQDA software as one of the available CAQDAS type software. First, the groups of actors forming discourse(s) were selected. Based on the analysis of the context presented earlier, it was determined that five groups (random order) form the list of social actors building the discourse on energy transition and phasing out coal in Poland during the studied time period: (1) municipalities and mining communes, (2) government, (3) other politicians, journalists and commentators, (4) ecological organizations and (5) representatives of the miners' trade. The aim was to reconstruct the storyline of each group and to analyse the discursive strategies used by each group of actors, as identified by Cilia, Reisigl and Wodak [52]. A corpus of texts for analysis was then compiled. This discourse consists of interviews provided to the media, post-meeting speeches or press conferences given by representatives of the above mentioned five groups of social actors between September 2020 and May 2021. These interviews were made available online in a written form or in the form of recordings of interviews and radio and TV talks. They were categorized according to the author's criterion and then collected in five text files, each file assigned to a particular group. The texts were collected according to the methodology used in CDA until a certain level of saturation was reached, which is achieved when each newly found text is a reprint of another and brings in no new representations [53]. In this way, 48 texts were collected. After their reading, by using an iterative approach, nine thematic areas were identified ((1) social contract, (2) coal phase-out and energy transition in Poland, (3) the future of miners and the Silesia region, (4) the European Union, (5) the state of mining in Poland, (6) opinions on government actions, (7) coal vs. alternative energy sources, (8) climate crisis, (9) and opinions on miners' trade unions). The thematic areas formed analytical categories for the CDA conducted in the next step, which consisted in identifying discursive strategies among the five strategies distinguished by Reisigl and Wodak (denotation and nomination, predication, argumentation, perspectivisation, amplification and toning) and meta-strategies, i.e., constructive strategies, perpetuation and justification strategies, transformation strategies and dismantling or destructive strategies $[52,54]$.

\section{Results}

\subsection{Situation in Poland in the Time Period under Review}

Poland is the largest hard coal producer and the second largest lignite producer in the EU following Germany [55]. The share of coal in the energy mix in Poland in 2018 was $76.8 \%$, while, for example, the value for Germany stood at $35.6 \%$, for the UK at $5.1 \%$, and for the EU as a whole at 18.9\% [55]; hard coal consumption in Poland in 2019 amounted to 68.3 million tonnes, decreasing by $8 \%$ compared with 2018 . The energy sector accounted for the largest share with $60.1 \%$ of consumption, while industry and construction accounted for $24.6 \%$. Households were also a significant coal consumer, 15.2\% [56]. Employment in mining and quarrying has declined steadily for many years (2007: 181,000, 2008: 182,000, 2009: 183,000, 2010: 173,000, 2011: 172,000, 2012: 174,000, 2013: 168,000, 2014: 160,000) [57] and stood at 124,000 in the last quarter of 2020. In 2019, coal mining in Poland in the Upper Silesian Basin, the largest coal basin in Poland, employed 78,500 people, accounting for $94 \%$ of all those employed in coal mining. The remaining 6\% worked at the Bogdanka mine in the Lublin province [58]. The average gross monthly salary in the mining industry in 2020 amounted to PLN 10963.43 and was approximately twice the average salary in Poland (PLN 5457.98) [59]. 
Hard coal mining in Poland has a long history and tradition dating back to the Middle Ages. Poland is also a country with large hard coal and lignite resources and for many years ranked very high in the world and in the European Union in terms of coal production, which reached its peak in the 1980s. Since the beginning of the 1990s, the process of reducing the use of coal, closing mines and a sharp reduction in hard coal mining in Poland began [60]. This is a common trend throughout the EU. The mining industry has had a specific role in Poland for a long time, both economically and socially. In the 1970s it was presented as a determinant of the economic development and a guarantor of economic stability. This was associated with a privileged position of companies from this industry, which was manifested, among others, by strong financial support from the government. During this period, efforts were made to increase coal production (with the record level of 200 million tonnes in 1979).

Although coal production grew steadily until the late 1970s, the sector and related industries became dysfunctional. The main reason was that within the Eastern Bloc, the countries that delivered a surplus of their planned production could expect additional investments, which combined with the lack of free market led to a suboptimal economic structure. The falling efficiency of collieries and lack of access to global markets were the main reason for their catastrophic condition in the 1980s [61]. In 1989, during the beginning of the transformational changes that led to the fall of communism in Poland, coal mining remained at a high level. At the same time, Western European countries reduced coal production by about one-third. The mining industry in Poland entered the restructuring period accustomed to receiving a highly preferential treatment and having a strong sense of entitlement [62].

Since 1990, the Polish mining industry has been undergoing a process of change and restructuring. The process of change and adjustment of the Polish hard coal mining industry to the conditions of the market economy was carried out in stages through changes in organizational structures supported by government sectoral restructuring programs. The most visible effects of the implementation of successive programs have so far included a significant reduction in the number of mines (from 70 in 1990 to 23 in 2016), coal production volume (from 147.4 million tonnes in 1990 to 72.2 million tonnes in 2015), coal sales volume (from 116.5 million tonnes in 1990 to 64.6 million tonnes in 2015), number of jobs, and merging of mines into larger coal corporations $[63,64]$.

Despite the significant public funds allocated to cover the costs of mining reforms since the 1990s and the extensive reduction in employment, successive reforms did not improve the economic efficiency of the mining sector. The reaction of mining companies to the changes taking place in their environment was insufficient here. This was due to the prioritization of economic goals over social ones, a deep-rooted organizational culture with a low tolerance for uncertainty and a lack of mutual understanding among stakeholders/participants of the process (owners of mining companies, managers, and employees). The changes that were taking place in the environment were identified too late and subsequently were addressed too late. The likelihood and scope of adverse changes had been underestimated very often, and the main method of levelling their effects was the belief that negative market trends would reverse [63]. In addition, political instability, consisting in frequent changes in the government and social tensions making a consistent long-term mining industry policy problematic, is mentioned among the main reasons for this serious setback. Moreover, the economic and social challenges of restructuring, such as withdrawal from the labour force or retraining, as well as the weakening of an important source of cultural identity of the inhabitants of the region (Ślaskie Voivodeship), where most Polish mines are located, were not met. It was also too late to provide support for local communities suffering the consequences of the transformation changes in the mining industry.

Up until 1998, the reforms in the mining industry took a sectoral rather than a regional or local perspective. It was not until 1998 that the need for cooperation between the central government and mining municipalities was recognized, but the policy was introduced 
too late and support for municipalities was insufficient [61]. It is also worth mentioning that miners' trade unions are a significant factor impeding the restructuring of the mining industry at every stage. It is their strength that produced high employment and high wages, and it is to their credit that Polish miners are an extremely powerful group compared with the status of miners in other countries: Polish miners work fewer hours a day and fewer days a year, have extra days off, extra monthly pay, and the possibility of early retirement. They exert political pressure through lobbying, direct talks with politicians, and strikes [64]. The largest strikes of miners against closing mines take on the form of mass demonstrations, which at times turn into regular fights with the police, or underground protests. Strikes, for example, took place in 2015 as a trade union response to closing of mines; the protests stopped only after the Parliament had agreed to a special law on mine restructuring.

Parliamentary elections were held in Poland in 2015. They were won by the Law and Justice Party (PiS), which had a strong pro-coal stand. The situation of coal companies, mainly public ones, was bad. Kompania Weglowa was in a particularly difficult situation and was threatened by bankruptcy. In order to take over the assets and liabilities of the Kompania Weglowa company on the brink of bankruptcy, the joint-stock company Polish Mining Group (Polska Grupa Górnicza (PGG), Katowice, Poland) was established by which many mining companies were saved from bankruptcy. The Polish Mining Group was recapitalized by entities from the public and private sectors [65].

Although there are other mining companies in Poland besides PGG, some of which are highly profitable, coal mining has generated losses over the past few years. Despite some temporary increases, there has been a general decline in coal production, mining efficiency, coal consumption and coal imports. Prices of coal, costs of miners' remuneration and employment, costs of coal production and stock that is not sold are rising all the time while the demand for coal is expected to fall. This allows the voices in favour of closing mines to gain strong support especially because they are based on economic data [66]. If environmental arguments coming from the EU in the form of the Green Deal are added, despite the current government promising that mines will not be closed and assuring that coal resources will be sufficient for the next 200 years, Poland is faced with the necessity of phasing out coal. The arguments in favour of not closing the mines are based primarily on a very strong and long-standing fear of energy security in Poland and the voices that Poland's national energy is based on coal, which is considered to provide cheap and stable electricity [60]. It is also important to note that mining in Poland has deep-rooted and strong traditions and is part of the cultural identity of Upper Silesia, the region where the mining industry is concentrated and whose future depends on the success of the transformation, and as found in a recent study, the majority of Silesian miners believe that coal mining should not be moved away from [67]. On the other hand, there was and is a growing interest in green energy among Poles [68]. This is the context in which the process of phasing out coal mines in Poland, which is expected to last nearly 30 years, has begun. One of its elements is the so-called social contract for the mining industry signed in May 2021.

Yet, around the world, the concept of bio-economy has emerged and trends to limit global warming have developed $[69,70]$. These were expressed in the Paris Agreement, which was adopted at the Paris Climate Conference (COP21) in December 2015, which is the first-ever universal, legally binding climate contract. It sets out a global action plan to save humanity from the threat of far-reaching climate change by limiting global warming to below $2{ }^{\circ} \mathrm{C}$ and aiming to keep it at $1.5^{\circ} \mathrm{C}$ [71]. Achieving this goal is possible by drastically reducing fossil fuels, for it is fossil fuels that have made the energy sector the largest emitter of greenhouse gases, and hence the major contributor to global warming [72-76] and it is low-carbon electricity that is a prerequisite to reduce fossil fuel use and to mitigate $\mathrm{CO}_{2}$ emissions $[77,78]$. This problem is taken particularly seriously in the European Union [79]. Some EU countries that are major producers and consumers of coal agreed to withdraw from its production and use by starting their coal phase-out. In 2015, the UK government announced a commitment to move away from coal by 2025 , which was the first 
commitment of its kind made by a government. Other countries planning to move away from coal that soon followed included France with an exit planned for 2022; Denmark, 2030; and Germany, 2038. Eastern and Central European countries rely largely on coal in their electricity production and fear that an unconsolidated transition to other forms of energy production can have a negative impact on their economic growth [80]. That is why the concept of just transition emerged. It is the process of changing from a carbon intensive economy to a zero-carbon economy, with particular attention to the wellbeing of local people in terms of continued employment and the environment in which they live. It is about creating alternative industries and providing jobs for those who will lose them as a result of the gradual closure of companies such as mines and power plants. To mitigate the social impact of this process, the EU budget for 2021-2028 introduced the Just Transition Mechanism. It is a set of financial tools to provide support to mining regions. The energy transition is therefore intended to be a just transition.

\subsection{The Course and Nature of the Talks Leading to the Signing of the Social Contract}

Between September 2020 and April 2021, so for about 7 months, the content of a document called the social contract was negotiated in Poland. Before that, there was a protest of miners, which ended with signing of the contract. It was in this document that the date of Poland's transition away from coal was first set for 2049. The social contract negotiated later is the fifth such contract in the mining sector in Poland over the last 30 years. It contains jointly agreed regulations on financing mechanism for hard coal mining companies, salary indexation, principles for the construction and implementation of the so-called clean coal facilities, establishment of a special Fund for Silesian Transformation, guarantees of employment, and a social benefits package for employees of mines in liquidation. The key element of the social agreement is the social protection package for employees from the mines in liquidation. All these solutions are intended to guarantee stability on the Silesian labour market. The agreement also states that work will be undertaken to create an additional system of support for specialist mining companies cooperating with hard coal mining, and for mining communes.

The social contract continues to develop and specify the contract concluded by the miners' unions with the government representatives on 25 September 2020. At that time, the time frame for the operation of the Polish energy coal mines was outlined until the end of 2049, during this period, the gradually closing mines were to be subsidized by the state. However, the European Commission must agree to this solution, and efforts for the notification of the contract are to start immediately after it is signed. However, the European Union may not agree to the agreement, as there are specific provisions in the EU law on State aid for hard coal mining, and they do not currently provide for the possibility of granting aid to operating mines. An additional complication is the fact that the European Commission is currently examining the climate impact of proposed state aid measures, and the EU competition law is in the process of being adapted to the goal of climate neutrality by 2050 .

The European Commission's approval is a necessary condition for the contract to enter into force. The social contract was supposed to be in place by 15 December 2020, but the negotiations were eventually prolonged, and the contract was finally concluded on 28 May 2021. Between September 2020 and 26 March 2021, 15 plenary and working negotiation meetings were held, during which most of the content of the contract was decided upon. The highlights of the negotiations are presented in the timeline below (Figure 1). 
25 September 2020

- Contract between the government and the protest committee of the miners' trade unions

September 2020-March 2021: several plenary and working meeting of the government with trade union representatives, discussions, exchange of projects

18 March 2021/19 March 2021

- Another round of negotiations (15 hours), suspended, with no agreement on two issues: wage indexation and guarantee of employment until retirement, deadlock

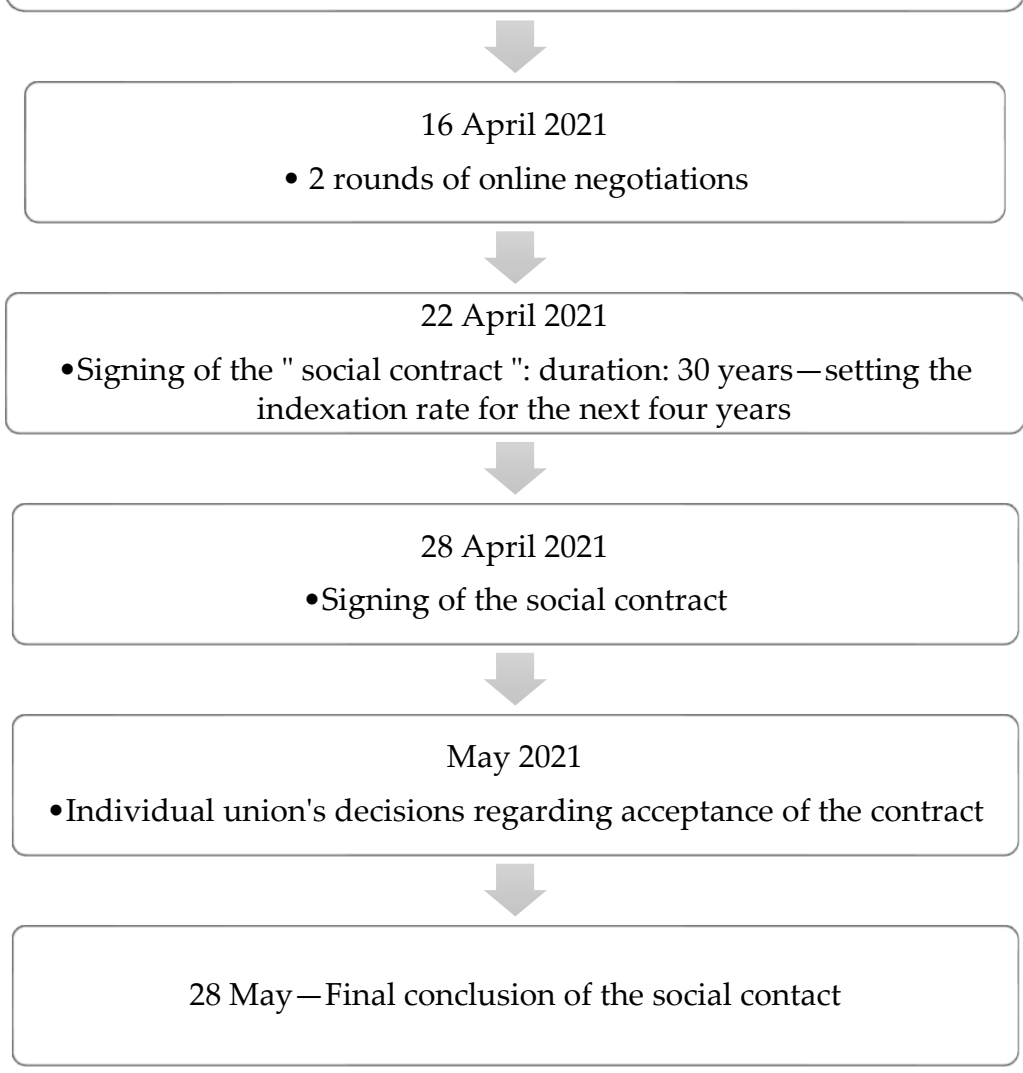

Figure 1. Timeline of the government's negotiations of the social contract with the miners' trade unions. Source: author's own compilation.

The talks were attended by the government representatives and representatives of the miners' trade unions. MPs and representatives of the local governments of the mining municipalities did not participate in the talks. Initially, the negotiations were to be concluded and the contract was to be signed in December 2020. However, the negotiations were prolonged because the parties were not able to reach an agreement on two of the most important issues for the representatives of the mining industry: a guarantee of employment in the mines until retirement and salary and wage indexation, i.e., adjusting salaries and wages to the inflation rate (Figure 2). 


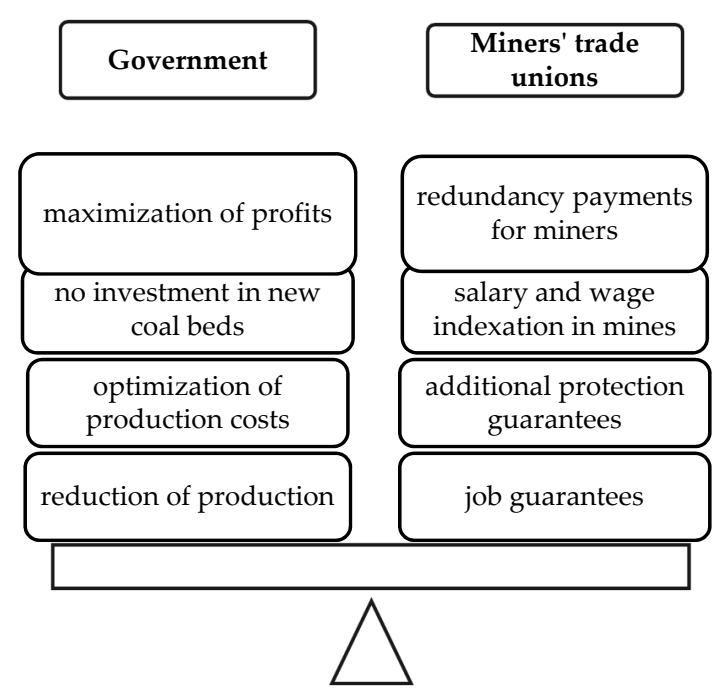

Figure 2. Arguments of the parties in the negotiations of the government's social contract with the miners' trade unions. Source: author's own compilation.

The signed contract is five pages long and the text of the contract was not made available to the public, nor were any drafts of the document; information on its content was obtained through journalists. The key provisions of the contract cover three areas and include a timeframe for closing mines, subsidies to their budgets, and a social package for miners leaving their jobs (Mining Social Package (MSP)). The details of the timeframes for coal mines were initially established at the time of concluding the September 2020 contract, which provided for the phasing out of coal mines by 2049, state aid for the mining industry during this period, social protection for miners, and mechanisms aimed at supporting the transformation of the region of Silesia. The social contract also includes a provision on guaranteeing employment for underground mineworkers and coal processing plant employees until the moment of their becoming eligible for retirement pension. Should it not be possible to ensure continuity of employment by transferring them to another plant, such employees will be able to receive social benefits (welfare allowance). There is also a provision that detailed solutions concerning this issue will be stipulated in the Act on the Operation of the Hard Coal Mining Industry. In addition, the document provides for a payment of PLN 120,000.00 in the event that the mine closes before 2049 and mineworker is not yet entitled to pension benefits and does not have a job opportunity in another colliery. Miners' salaries are to increase each year by a few percent (in 2022 by 3.8\%; in 2023 , by $3.5 \%$; in 2024 , by $3.4 \%$; in 2025 , by $3.3 \%$ ), and the government is to form lowcarbon investment projects. According to the contract, the government is to propose the location and provide the conditions for launching those investments by mid-2022, and their construction and commissioning are to be completed between 2023 and 2029. A special Silesia Transformation Fund is to be established to coordinate the transformation of post-mining, industrial and post-industrial areas with the transformation of the Province of Silesia (województwo ślaskie). However, not all of the expectations expressed by the parties to the social contract have been met. The miners did not manage to secure compensation for the salaries of those who would independently find employment outside the mining industry (entrepreneurs running, for example, car repair shops, who would like to employ their colleagues leaving their coal mine, would receive a subsidy to supplement their salaries) and the contract will not provide security for the entire mining industry. The government failed to push through the implementation of a bonus system in mines.

The document drawn up on this basis became an element of a pre-notification motion concerning the programme of transformation of the hard coal mining which was submitted by the Polish government to the European Commission. The system of instruments for supporting the mining industry proposed in the motion by the Polish government is based on covering by the budget the costs of the physical liquidation of the mines and the so- 
called extraordinary costs, i.e., mainly the mining social package for the miners and, which was not performed before, budget subsidies for reducing coal production. Part of the prenotification proposal are the mines' operational programs, including detailed production guidelines and production capacity reduction plans supported by the state. Poland is to apply for subsidies under the EU Treaty on the grounds of "important economic interest". However, such assistance must be consistent with the EU's objectives, i.e., first and foremost reducing $\mathrm{CO}_{2}$ emissions by 2030. If the EU agrees to the Polish programme, it will be possible to put the social contract into effect.

\subsection{Discursive Strategies in the Statements Made by Actors in the Transition Process}

Both during the negotiation talks and directly after the signing of the social contract, there were numerous comments in the media made by all five groups of the actors/participants in the transition process. As stated in the methodology section, those comments were collected for the purpose of this study and processed using the MAXQDA software. In each of the five files, in which the texts of a given group of actors were collected, segments corresponding to the nine identified thematic areas were coded. Thus, a list of nine themes and statements on each theme was obtained for each group of the actors. In the discussion, referring to the catalogue of basic types of discourse meta-strategies distinguished by de Cillia et al. [52] the types of strategies used by each group were identified and included: reinforcing, constructive, transformative and dismantling or destructive strategies. Reinforcing strategies aim to reproduce dominant narratives, constructive strategies are used to unify and identify, transformative strategies are used to change the picture according to the outline defined by the speaker, while dismantling and destructive strategies are used to de-mythologize and to dismantle. The frequency of occurrence of the themes in all the analysed speeches is shown below (Figure 3).

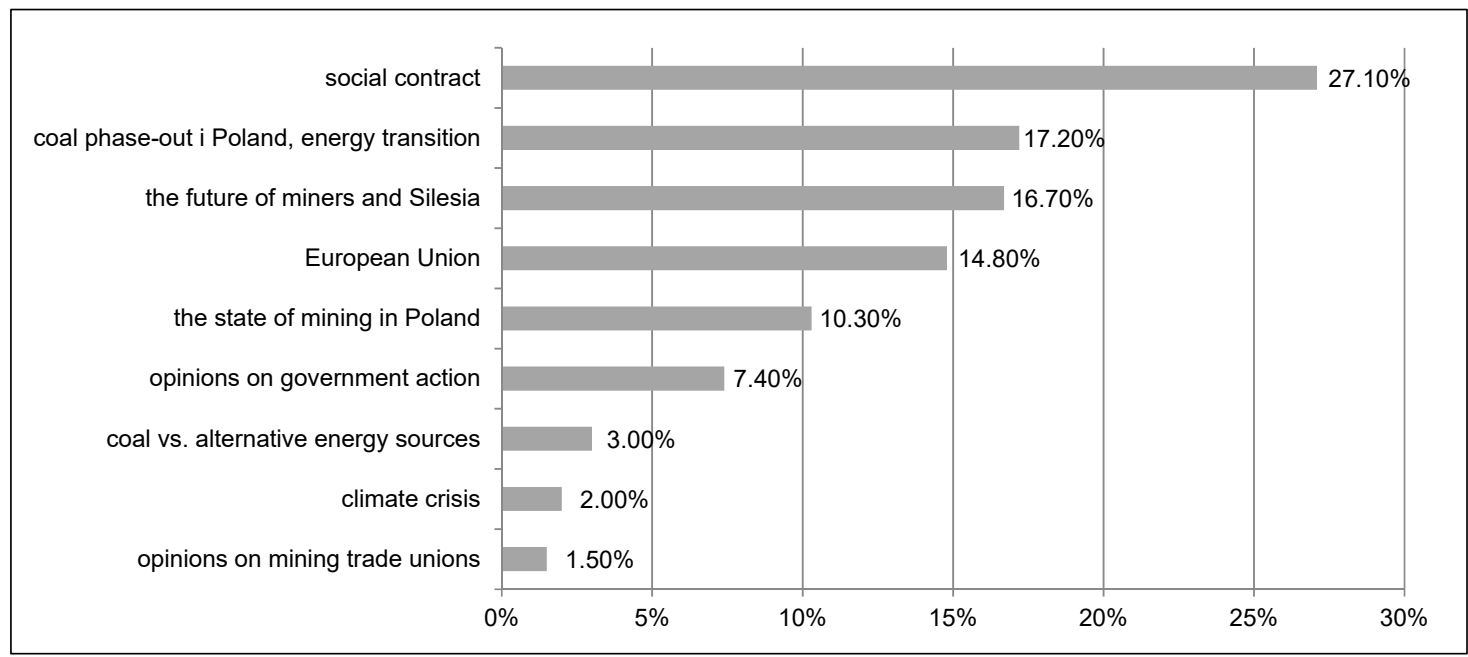

Figure 3. Presentation of the nine themes in the discourse. Source: author's own compilation using MAXQDA.

The theme most often discussed was, by far, the social contract itself, because the contract and its negotiation were the reason for interviews and discussions, it was a critical moment in the whole transformation. Then there were the themes of coal phase-out in Poland and energy transition and the future of miners and of the region of Silesia. The negotiated contract brought up the theme of the role of the European Union in the Polish transformation as well as an evaluation of the actions taken by the Polish government. The least was said about the role of coal in Poland in the future in contrast to alternative energy sources and the climate crisis. The fewest statements were the opinions about the actions of trade union representatives. The following matrix of codes and statements generated in MAXQDA shows the frequency with which particular groups of actors addressed a given theme (Figure 4). 


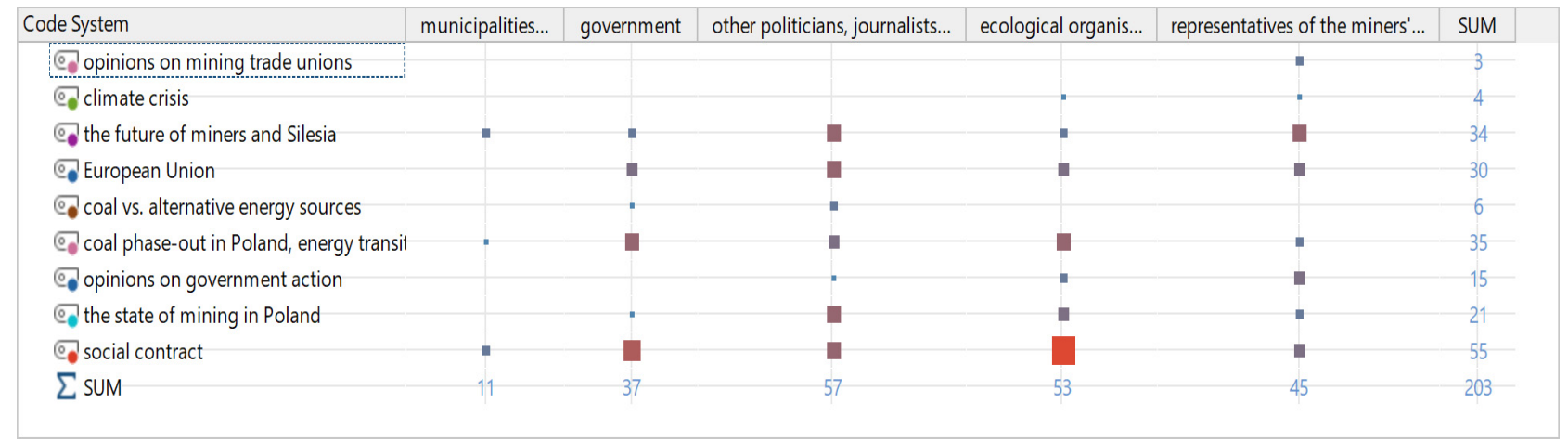

Figure 4. The matrix representing the codes and the statements of the actors in the discourse on the energy transition in Poland. Source: author's own compilation using MAXQDA.

As can be seen, the social contract was the most frequently discussed theme, all groups of actors expressed their opinions on this subject. All actors also referred to the future of mining and of the Silesia region as well as to the coal phase-out in Poland and energy transition. There are, however, some themes on which not all actors spoke and those included opinions about the government's actions, the climate crisis and also opinions about the actions and activists of the miners' trade unions.

\subsubsection{Discourse of the Representatives of the Mining Municipalities}

Representatives of the mining municipalities did not take part in the negotiations and spoke less frequently in the media. On the issue of the future of Silesia and its miners, mining municipalities and their representatives reinforce the topos of Silesia and associate the energy transformation in Poland with the success of transformations in Silesia, and the transformation is presented by the municipalities as a process which has consequences for the whole economy:

"We need a transformation programme, a transformation programme for our region so that Silesia can succeed. Let us remember that Silesia is the largest industrial region, and if we do not succeed here, if the transformation does not proceed properly, the other regions of the country will not succeed either."

Their discourse seeks to change the perception of the role of municipalities in the transformation; through the use of forms "we" they attribute to themselves the causative power ("we agreed to close down the mining industry all too quickly"), through their argumentation they aim to raise the status of Silesia, and they bring up arguments related to the labour market. As far as the transformation and coal phase-out are concerned, the municipalities are afraid of the transformation process and its social effects, which have been experienced in other countries:

"We want to learn from the good examples of our closest neighbours-the Czech Republic. But also from Germany, because we are also watching the situation there, or from England. We do not want to make similar mistakes that were made during the transformations earlier."

A serious allegation is raised against the negotiators of the social contract, who are accused of excluding mining municipalities from the negotiations. The municipalities stress that the negotiations became binary talks between the government and the trade unions. The municipalities remain aware of their powerlessness, their exclusion from the dialogue and their inability to influence the process of transformation and decarbonization in Poland, with the expected severe social consequences in the form of unemployment.

\subsubsection{Discourse of the Government}

In the image of the transformation created by the Polish government, the social contract that has just been concluded comes to the fore, of course, as does the energy 
transformation of the whole country. In the context of Silesia and the future of the miners, the Polish government also refers to the topos of Silesia as a region of labour, but there are also suggestions in the form of nominations and predications, which create an image of Silesia as a region that holds a good capacity for change and will thus be able to cope with the energy transformation:

"Silesia is a region of innovation and hard work.-Only it is its character that is changing. Today it is more of an intellectual nature. It is work on new technologies, it is development of research."

The government's role is indisputable here, through the form "we" the government creates an image of the state/government as one that will be able to transform Silesia in a way that will ensure its just transition, which in the understanding of the government's actors means above all providing jobs for the miners leaving the mining industry. The issue of employment is a dominant theme in the government's discourse. The theme of the European Union comes up relatively often in the governmental discourse. It is worth remembering that whether the signed contract will be implemented depends on whether the European Union will agree to the programme contained therein. For the energy transformation in Poland, the theme of the European Union is therefore important not only because of its image but also for formal and legal reasons. In the governmental discourse, the European Union appears primarily as an institution to which one must submit, determining the directions of the government's actions, a strict sentry imposing conditions. The phrase "this leaves us with no other choice" is frequently used in this discourse.

However, there are also optimistic voices hoping for understanding on the part of the European Commission due to Poland's "special situation" in connection with the imminent energy transformation, and occasionally emphasizing the correspondence between Poland's and the European Union's environmental goals:

"We are aware that it will be a difficult process, but Poland is in an exceptional situation among the EU countries as regards the use of coal in the energy mix. Therefore, I count on the understanding and favour of the European Commission in this respect."

"I only need to remind you that the process of coal phase-out in Poland is fully consistent with the European Commission's climate policy. The transformation of the sector is a great sacrifice, not only for Silesia, but for the whole Poland. In return, we do expect to be understood and guaranteed the time needed for the transformation."

The transition to fuels other than coal is presented in the discourse of the government as the only option and an inevitable process. Emphasis is placed here, though relatively rarely, on the environmental safety of energy sources.

The discourse of the government is calm and balanced, yet full of optimism and is meant to provide a sense of assurance and security. The statements from the government are limited to just a few people, and they are brief. The government guarantees that "thanks to the contract, the transformation process will proceed in an orderly manner, as a result of a certain consensus". In the governmental discourse, the energy transformation "is a consistent, smooth, planned operation that will take place in a controlled manner", and it will take place in all possible areas, none of which will be neglected.

In the governmental discourse there are also cases of returning to the topos of mining as an element of identity and culture; the image of coal as a "national asset" which must be preserved and protected is maintained. It is connected with romanticizing mining and nostalgic memories and there are voices saying that "we would prefer not to sign this document". However, this thread of the discourse is somewhat weaker:

"It is not as if we met here because we had come to the conclusion that we must move away from mining, which for many years had been an extremely important branch of Polish industry. Mining must be seen not only as a branch of the 
economy, but also as an element of this region's identity, culture and tradition. This is not the reason why we are here. But because in such conditions we have found ourselves here in connection with the climate policy of the European Union, in connection with the fact that coal today proves to be the most expensive fuel in the final analysis, not because it is mined, but because it is burdened with charges connected with $\mathrm{CO}_{2}$ emissions."

This kind of discourse is present in the government's discourse on the concluded social contract. The document is called "historical", "good", "important from the point of view of energy security of Poland", "road map", "the only proposal that can be responsibly addressed to the hard coal sector, which indicates the directions of transformation of the hard coal mining sector, guarantees social security to the miners, and ensures energy security to Poland". The governmental discourse promotes a major significance of the social contract and stresses the importance of the moment in which the country finds itself: "Big success. We are taking a historic step towards a good energy change".

In the governmental discourse, it is also emphasized that the social contract is an agreement developed jointly, that "it is an example that such a social dialogue can be successfully conducted (...)" and although there were some controversial elements, the whole contract is an effect of cooperation and consensus.

\subsubsection{Discourse of Commentators and Politicians from Outside of the Government}

In the discourse of other politicians and commentators, a wider range of themes appear, and statements include more argumentation and stronger value judgments, and they often combine these strategies. They adopt the perspectives of different groups, positioning themselves as representatives of broad social groups:

"The inhabitants of Silesian cities are getting tired of coal: they do not want new mines to be opened, they do not want their houses to cave in as a result of mining damages and for undeveloped post-mining areas to haunt them in town centres, and they do not want their children and relatives to die from smog-related diseases. Allow me to remind you that among ten European cities most threatened by this problem, as many as three are located in the Province of Silesia!"

This discourse is very diverse, and for this reason it would only be natural to divide it into different categories, which can be defined on the basis of the opinions being held by supporters or opponents of the transition process. Characteristic of these groups is the tendency to cite facts, i.e., numbers, events, names, and dates. This is particularly the case in the theme of the future of Silesia and miners. Substantive remarks give this discourse a constructive, reinforcing character: each of the speakers aims at reinforcing the image of Silesia which they have adopted, and sometimes these images are very different ranging from those in which Silesia is a strong region, which will cope with the transformation, to those in which it will suffer greatly from the effects of the transition, e.g., from the lack of jobs. Politicians associated with the government maintain the image of Silesia as a strong region, which will manage; they refer to the past and to similar programs for Silesia, which were implemented earlier; they believe that "we are a large country, which is in the process of development and our pace of work allows for the fact that these jobs will appear, not only in Silesia, but also outside Silesia". Other commentators, on the other hand, believe that the transformation concerns not only miners, but also their families, companies related to mining and coal, and that social protection provided for in the social contract does not extend to these groups.

In this discourse, of course, the European Union also appears; although, as in the case of the government, it is perceived as a guardian of the law, with "climate ambitions", to which Poland must submit. Politicians and commentators associated with the ruling party also emphasize the real, in their opinion, reasons for the high costs of hard coal mining in Poland: 
"We are not closing mines mainly because they are harmful to environment, but because the costs of producing electricity and heat from coal resulting from high $\mathrm{CO}_{2}$ emission fees are very high."

As far as the European Union is concerned, there are hardly any value judgments in the discourse of commentators and politicians. The European Union is depicted as a source of law, not always fully comprehensible, but still a law which is not questioned. In this sense, the discourse reinforces the image of this institution in such a spirit:

"We have to look realistically at what the European Union is doing. The Union has put a green agenda on the table and we have to go in that direction as Poland, because we are in the European Union."

The discourse of commentators and other politicians also includes expert voices. If experts are not affiliated with any of the parties to the contract, they use substantive arguments in the discourse, generally creating a critical image of the proposals contained in the signed document, predicting that the European Union will not agree to the concluded contract because its provisions are not consistent with EU law. In the expert discourse, an even stricter image of the European Union as the guardian of the law is created.

In this discourse, a coherent image of the energy transformation awaiting Poland is also created. This is performed mainly through judgments, but also by referring to some commonly known facts, which are indisputable:

"I take a negative view of the idea of setting fixed dates for mine closures. For anyone who knows the specifics of the mining sector in Poland, this is not a rational idea. Geological and mining conditions change individually depending on the mine. The economics of extraction itself also changes. We also do not know the demand for hard coal in the electric power and heating sectors in the perspective of the transition period. As we know, prices of $\mathrm{CO}_{2}$ emission allowances have already exceeded the level of 47 euros per one tonne. Production of electricity and heat from hard coal and lignite is therefore already unprofitable at present. Therefore, Poland will have to withdraw more quickly from the production of electricity and heat based on hard coal and lignite. This fuel will be replaced by other energy carriers and RES."

In the context of Poland's departure from coal, experts in their discourse express concern about a number of issues, such as a substitute for coal, energy poverty, the possibility of using coal in an alternative way (underground gasification), or gas as an alternative energy source, subsidies for coal and other energy sources, as well as Poland's chances of receiving funds from the European Union or also unemployment issues in Silesia. Expert discourse in this context becomes a value-argumentative discourse. Experts create, above all, their own image: they often use pluralis majestatis, which is supposed to make them credible as a group that knows what they are talking about; they use strategies of exclusion, as in excluding other actors ("for all who know", "as we know"), but they also do not shy away from specialized terminology, often explaining these terms and taking on the role of a mentor:

"We will avoid the phenomenon called "lock in effect", i.e., a forced continuation of the chosen technology. And then, we will not be likely to have to face talks on a social contract for the gas industry."

Expert discourse is extremely broad; experts clearly create themselves as a single group, build their image as independent of the government, among which each maintains their autonomy:

It is also very often experts' opinion that no date should be set for Poland's departure from coal:

"I believe that the European Union will be in contract with this project and we will still be able to continue our mining activities until 2049." 
"As for the mine closure schedule itself, I believe that it is unrealistic, and the fact that it includes a fixed date for closing further coal mines has nothing to do with the knowledge of geology or economics."

Experts call the social contract a "political gesture", "theatre", or a "flop" and point out that the signed document is a contract only between the government and the miners.

\subsubsection{The Discourse of Environmental Organizations}

Environmental organizations are also a group that speaks broadly in the context of signing the social contract. At the same time, it is the only group of actors to raise the issues of the climate crisis. Environmentalists, similar to experts and other politicians, use strategies of judgment and argumentation, citing scientific studies, figures and facts. They are also clear about the date of the transition away from coal:

"The effects of the climate crisis are already threatening our health and lives-also in Poland. The IPCC report makes it clear that in order to stay on the path of up to 1.5 degrees, OECD countries, including Poland, should phase out coal by 2030. Maintaining coal and delaying a balanced transition is against the interests of the Polish society."

In the context of the future of Silesia and the miners, environmentalists emphasize the issue of employment in Silesia as they believe that "the protection of miners is unrealistic, because the government, by promising a guarantee of employment, is holding them in an unprofitable sector which will close down much sooner than the agreed schedule" and they believe that an active job search programme has been insufficiently developed. In their discourse, the European Union is presented as an institution that makes the law and protects it, the final instance on which it all depends, but which at the same time is rational and acts in the interest of all citizens, and distributes aid fairly:

"The contract provides for further state aid to maintain unprofitable mines, except that subsidizing the operation of mines is against the EU law. It is hard to imagine that the European Commission would make an exception for the Polish government."

The same is true of phasing out coal and the energy transition by adopting a very different tone than the other groups:

"The transition away from coal will take place much faster in Poland. Firstly, because coal in Poland is simply running out, and the last tonne of coal will be mined in a dozen or so years at most. Secondly, energy from coal is becoming more and more expensive, and the mining industry itself is drowning in debts."

It is also the only discourse in which there is an "environmental" argument for closing the mines:

"The demand for coal is falling and will fall faster and faster. Already, most coal-fired power plants are scheduled to close by 2035 at the latest, and given the need for climate protection, plants will have to close even sooner."

This is also partly a dismantling discourse, with environmentalists using value judgments and metaphors aimed at presenting the image of the planned transformation in a completely different light. They consider the contract to be "fiction", "coal collusion", another fanfaronade" and "an empty promise of the government", "deception" and "a blasphemy of the Polish government". They call the contract dishonest, against the interest and the will of the Polish society; they believe that Poland should phase out coal by 2030 and the presented schedule is "detached from reality" and based on wrong assumptions. In their statements about the government, environmentalists are very categorical:

"It seems that this hookup is so that the government can blame the "evil EU" for the closure of the mines. It is cynical and irresponsible behaviour of Minister 
Sasin. The government, instead of preparing a soft landing for the miners, made them jump into an abyss."

Environmentalists seek to undermine government decisions and actions:

"It is a pity that by buying itself time, the Polish government has sold the future of 80,000 miners and their families."

"It is cynical and irresponsible behaviour of Minister Sasin and the government of Mateusz Morawiecki, who condemn us to chaos in the mining and energy industries and to sudden closures of mines or power plants, which will be forced, if not by climate policy, then by economic factors."

They also engage in a transformative discourse on the state of the mining industry, emphasizing its disastrous economic condition: the high cost of energy produced from coal, as well as its losses and debts. Similar to most actors, they also like to adopt the grammatical form of "we" in order to say that they speak on behalf of all citizens and that they are their voice.

\subsubsection{Discourse of Miners' Union Representatives}

Representatives of the miners' unions speak on virtually every theme presented in the Figure 3 with the exception of alternative energy sources, and at the same time are the only group that speaks about themselves. It is also the only discourse in which war rhetoric and metaphors are identified. The trade unionists speak of themselves as fighting, working on the contract, reminisce about strikes which are the last resort for them. As far as the climate crisis is concerned, they are unambiguously critical, appealing to the Prime Minister not to succumb to the "climate religion". They use strategies of prediction and argumentation, valuing negatively and entering into polemics with a positive narration about the future of Silesia and mining, especially about the promised jobs:

"The previous governments announced that the car industry could be an alternative to the jobs lost in mining. But the truth is brutal: Silesian factories today are nothing more than "assembly plants". We have not become any kind of innovation valley. Therefore, when I hear the announcements made by PiS that mining jobs are to be replaced, among others, by the Izera electric car factory, I absolutely do not believe it. These are fairy tales which will have absolutely nothing to do with reality. The same will be true of photovoltaic panel factories or windmill turbine factories. No other employer will be able to offer wages such as those at PGG" (Polska Grupa Górniacza (PGG), the Polish Mining Group).

In their statements, the miners' representatives show a lack of faith in a painless transformation and a conviction that the mines will be liquidated anyway. They are convinced that they no longer have any influence either on the decisions made by the European Union or on the government's actions. The miners' representatives in their narration refer to the history of Silesia, the topos of miners as builders of the country, who are now treated in an ungrateful way:

"100 years ago the victorious Third Silesian Uprising broke out. Our grandfathers gave Silesia to Poland, and we would expect that today, in these difficult conditions, Poland will not forget about Silesia and will not abandon Silesia."

The statement of the main representative of this group has a significant meaning here:

"I also hope, although no one can be sure, that Silesia will not become a land of old people and turned off lights, that the transformation will be really fair, and that it depends on the signatories of the contract and parliamentarians whether Silesia will continue to be the industrial heart of Poland."

In the narration of the miners" representatives, Silesia was and is a "lifeboat for the whole country", where the image of miners and Silesia is being constructed based on their romanticization. 
On the subject of the European Union, the miners' representatives create an image already familiar because it has been created by other groups in which the EU is a guardian of the law, not fully comprehensible, but an adamant adversary. Miners declare readiness to negotiate with the EU on the one hand, while on the other hand they threaten that if the EU's position on the contract is any harsher, they will announce the defence of their interests, protests, even demonstrations in Brussels. Critical voices are heard here, towards the EU and the relationship between the EU and Poland. It is also the only discourse in which the speakers resort to irony in relation to the EU:

"If the European Union wanted to tighten up the provisions of the social contract, then there is no such contract that could not be renegotiated. If the timeframe were to be shortened by a year or two, we would probably not despair about it. On the other hand, if the European Union decides that, well, I will use the expression you dirty Polish people are still fighting for this coal, and the EU is supposed to be beautiful, wonderful and green, you must liquidate this coal in the year 2035, then the situation which I have spoken about will probably arise. Firstly, Silesia or death, because this is how the government of the Republic of Poland should behave, and secondly, our flags in Brussels may also appear in front of the headquarters of the European Union, in front of the headquarters of, for example, Frans Timmermanns, who is one of the few European Union commissioners who contested the contract without even reading it. This is also an interesting image of the EU's approach to Polish affairs. The Union is beginning to resemble something that used to be called the Council for Mutual Economic Assistance. It is a system of orders and bans in which we, the citizens, get our asses kicked. We have to carry out these orders for us, for the sake of the EU and for our own sake, which I think is complete nonsense."

Miners' representatives use a transformative discourse in relation to themselves in the context of Poland's coal phase-out. They create an image of their group as a group aware of the necessity of phasing out coal, but they argue that the country's energy security is at risk and that the government has performed little in this respect. They also hope that technologies will emerge that will make it possible to return to coal. Trade unionists often express their opinions about the government's actions and their discourse usually takes the form of predicates which are strongly characterized by values. They also regret that the contract was not negotiated by the Prime Minister himself, nor by a minister, but by a deputy minister. They evaluate the negotiated social contract positively, saying that it could not have been better.

\section{Discussion}

The aim of this study was to draw a picture of the Polish transformation as seen through the eyes of its actors. The discourse analysis conducted confirmed this assumption. The various actors in the transformation behaved in a predictable manner, and the discourse itself does not inspire optimism about rapid transformation. The discourse analysis reveals that the cited scientific theories about expected social difficulties have been confirmed.

The dominant discourse in terms of numbers is that of other politicians and journalists as well as environmental organizations; it is the most numerous in the collected texts. The least heard was the voice of the representatives of mining municipalities. However, it should be noted that the discourse of the trade union representatives and government representatives dominated in the most popular media, i.e., television and radio, their voices were the most strongly heard. This confirms that the discussion about the transition away from coal in Poland has turned into a binary conflict between the government and the miners and that all other groups of actors have been excluded from the conflict and now can only observe the negotiations. The energy transition is a theme that seems to concern only one social group, i.e., the miners, and one area of the country, i.e., Silesia. This is how this discussion differs from the way it is discussed in other countries. In Germany and Canada, for example, special stakeholder committees have been established, i.e., arenas where 
spatially and thematically diversified stakeholders meet and are required to (re)negotiate their priorities [81]. At the same time, the situation in Poland can be compared to analogous situations in Germany and the UK, which are comparable to Poland as coal-based countries. In both these countries there were forces that slowed down the move away from coal [24].

Understandably, the most frequent theme in the discourse was that of the social contract. All actors, without exception, referred to this theme, with a multitude of opinions on the document itself and its various descriptions, from very positive to extremely critical. The second most frequently mentioned theme was that of the coal phase-out and the energy transition. Almost as often there appears the theme of the future of Silesia; thus, these are the dominant issues discussed in all types of discourse. Energy transition and decarbonization are two themes that very often appear in the same discourse; thus, for the time being' they are seen as a process that will involve employment problems for miners leaving the mines. The strategies used in relation to this theme in almost all groups of the discourse actors are reinforcing strategies, based on the very familiar topos of Silesia as a region of labour and tradition, as well as the romanticization of mining. In this respect, the Polish mining narrative resembles that of a similar situation in Germany. Here, too, the closure of coal mines evoked a nostalgic mood. Here mining was romanticised and mythologised, and coal was part of the local identity and consciousness. Mining is a vocation and a way of life, and the topic of coal is a culture war [82]. This is the rationale for Poland to follow the German model of transformation in mining. This means that it will be a long-term transformation. The co-occurrence of these two themes in the discourses while neglecting topics related to energy sources alternative to coal and the climate crisis also shows that the storylines related to ecology do not constitute such a significant motif of the Polish transition process. Although they are present in the discourse, they are not yet a dominant storyline. Rather, it seems that the driving force behind the Polish transformation is the European Union, which is putting pressure on Poland as a member after all and forcing it to close mines and move away from coal. While the condition of the Polish mining industry also comes up, it is not the main cause of mine closures.

The discourse of the representatives of mining municipalities, who were rarely given a voice in the media space, is a transformative discourse as to the role of municipalities and a reinforcing and constructive discourse in the theme of transformation, which municipalities see primarily as the transformation of the entire region. For understandable reasons, a somewhat broader view is represented by the central government. Its discourse is relatively modest, balanced, positive, and constructive. The government avoids any negative assessment of the transformation itself, the signed contract and, finally, of the European Union as a catalyst for transformation. It is significant that also in this discourse the issues of climate protection do not appear as the main premises of the transformation, which is an inevitable process. The government discourse seems to be conservative, and one would expect a bit more transparency here. This is similar to other countries [83].

The discourse of commentators and politicians from outside the government is very diverse, extremely rich and dependent on the political option of a particular speaker, it can certainly be considered as a separate issue. It has features of the discourse of all actors. It is also rich in dates, facts, and terminology, because often the actors speaking here are experts in economics or mining, and they resort to providing facts as a discursive strategy aimed at providing credibility.

The two most interesting types of discourse are those of environmental organizations and trade union representatives. Environmentalists engage in a transformative discourse, seeking to change the perception of the European Union as the guardian of the law and crediting it with the ability to act according to logic, rationality, and they anticipate that the European Union will not agree to subsidize mines. In relation to the discourse of experts and other politicians, this is a very opposition-oriented, dismantling, and destructive discourse, as it seeks to overturn the narrative regarding the possibility and need for Poland to stay with coal. Here there are elements of the climate crisis as a motive for the energy transition. 
It appears, however, that the discourse of the miners' trade union representatives is dominant in the Polish media. It is them who most often speak out in interviews and at conferences and it is them who most often appear in the public space and who also most often spoke out on the occasion of the signing of the social contract. Their discourse on the theme of the energy transformation is constructive and reinforcing: the energy transformation will mainly affect Silesia with its topos of hard mining work and the spectre of unemployment and economic disaster, which is a familiar image in Poland. Thus, miners' unions in Poland continue the rhetoric of most trade unions on the topic of transitions, representing a perspective known as 'jobs versus environment' [84]. The miners' discourse is also extremely rich in metaphors, including war-related language, often reaching for colloquial language, which is intended to mobilize public opinion to take a firm stand on the side of the miners. What is characteristic is the dismantling and destructive character of the discourse in relation to the European Union, which appears here as an adversary or even an opponent. There is therefore a clear tension between supporters and opponents of coal. Those in favour of coal are not only the trade unions, but one has the impression that the government is also in favour. The opponents of coal are mainly environmentalists. Some studies show that most countries remain unwilling to give up their fossil fuel-based energy systems, despite the official announcements (Lee, Yang). Such tensions between actors in Poland allow us to conclude that the transition will also be slow in this country.

\section{Conclusions}

This study shows how all actors of the energy transition in Poland try to manage it through discourse, i.e., influence the public opinion and achieve their goals. The study naturally had its limitations, as the statements in relation to the signed social contract are of course thematically related primarily to this document, but they reveal the dominant narrative of Poland's energy transition. Thus, it was possible to verify the research hypothesis formulated in the introduction about the dominance of one of the current energy transition discourses in Poland, the tensions between the social actors of the transition process and the particular power of the coal regime discourse. If the media coverage is taken into account, the narrative of the miners' trade union representatives and their reinforcing discourse in relation to the role of Silesia and its anticipated situation certainly comes to the fore and it is this discourse that has been identified as the dominant discourse. However, the discourses of other politicians and environmentalists also remain quite significant. What can be seen here is an attempt to build completely different storylines, using different means: from the colourful and emotional language of the trade union representatives to the substantive argumentation of the environmentalists. Each group of actors manages the energy transition that is about to take place or is already underway in their own characteristic way, but the tensions between the coal regime and the actors opposing it are already evident. According to the theory of discourse, discourse shapes collective thinking and initiates social change. Such a diverse discourse of all social actors, with the concomitant powerful influence of the discourse of the coal regime, is likely to prove a significant obstacle to the energy transition in Poland. Since the research has revealed that the transformation will not happen quickly because it meets resistance from its actors, one can try to determine what the direction of future research should be. It would be useful to investigate the factors that can change the actors' attitudes. To this end, it would be useful to study the attitudes of actors in Germany, as the move away from coal in Poland may look similar.

Author Contributions: Conceptualization, J.K. and D.K.; methodology, J.K. and A.A.; software, A.A.; validation, A.A., J.K. and D.K.; formal analysis, J.K.; investigation, D.K.; resources, A.A. and J.K. data curation, D.K.; writing-original draft preparation, J.K.; writing-review and editing, D.K.; visualization, A.A., D.K.; supervision, D.K. and A.A. project administration, A.A.; All authors have read and agreed to the published version of the manuscript.

Funding: This research received no external funding.

Institutional Review Board Statement: Not applicable. 
Informed Consent Statement: Not applicable.

Data Availability Statement: Not applicable.

Conflicts of Interest: The authors declare no conflict of interest.

\section{References}

1. Androniceanu, A.-M.; Georgescu, I.; Dobrin, C.; Dragulanescu, I.V. Multifactorial components analysis of the renewable energy sector in the OECD countries and managerial implications. Pol. J. Manag. Stud. 2020, 22, 36-37.

2. Millot, A.; Maïzi, N. From open-loop energy revolutions to closed-loop transition: What drives carbon neutrality? Technol. Forecast. Soc. Chang. 2021, 172, 121003. [CrossRef]

3. Loorbach, D.; Frantzeskaki, N.; Thissen, W. Introduction to the special section: Infrastructures and transitions. Technol. Forecast. Soc. Chang. 2010, 77, 1195-1202. [CrossRef]

4. Goulet, F. Characterizing alignments in socio-technical transitions. Lessons from agricultural bio-inputs in Brazil. Technol. Soc. 2021, 65, 101580. [CrossRef]

5. Prouty, C.; Mohebbi, S.; Zhang, Q. Extreme weather events and wastewater infrastructure: A system dynamics model of a multi-level, socio-technical transition. Sci. Total Environ. 2020, 714, 136685. [CrossRef]

6. Sunio, V. Unpacking justice issues and tensions in transport system transition using multi-criteria mapping method. Transp. Res. Part D Transp. Environ. 2021, 96, 102887. [CrossRef]

7. Upham, P.; Virkamäki, V.; Kivimaa, P.; Hildén, M.; Wadud, Z. Socio-technical transition governance and public opinion: The case of passenger transport in Finland. J. Transp. Geogr. 2015, 4, 210-219. [CrossRef]

8. Malhotra, A.; Nandigama, S.; Bhattacharya, K.S. Food, fields and forage: A socio-ecological account of cultural transitions among the Gaddis of Himachal Pradesh in India. Heliyon 2021, 7, e07659. [CrossRef] [PubMed]

9. Zollet, S.; Maharjan, K.L. Resisting the vineyard invasion: Anti-pesticide movements as a vehicle for territorial food democracy and just sustainability transitions. J. Rural Stud. 2021, 86, 318-329. [CrossRef]

10. Westerveld, J.L.J.; van den Homberg, M.J.C.; Nobre, G.G.; van den Berg, D.L.J.; Tekletsadik, A.D.; Sjoerd, M.S. Forecasting transitions in the state of food security with machine learning using transferable features. Sci. Total Environ. 2021, 786, 147366. [CrossRef]

11. Markard, J.; Raven, R.; Truffer, B. Sustainability transitions: An emerging field of research and its prospects. Res. Policy 2012, 41, 956-967. [CrossRef]

12. Fouquet, R. The slow search for solutions: Lessons from historical energy transitions by sector and service. Energy Policy 2010, 38, 6586-6596. [CrossRef]

13. Zolfagharian, M.; Walrave, B.; Raven, R.; Romme, A.G.L. Studying transitions: Past, present, and future. Res. Policy 2019, 48, 103788. [CrossRef]

14. Diéguez, M.S.; Fattahi, A.; Sijm, J.; España, G.M.; Faaij, A. Modelling of decarbonisation transition in national integrated energy system with hourly operational resolution. Adv. Appl. Energy 2021, 3, 100043. [CrossRef]

15. Turnheim, B.; Geels, F.W. The destabilisation of existing regimes: Confronting a multi-dimensional framework with a case study of the British coal industry (1913-1967). Res. Policy 2013, 42, 1749-1767. [CrossRef]

16. Balzquez, J.; Fuentes, R.; Manzano, B. On some economic principles of the energy transition. Energy Policy 2020, 147, S0301421520305267. [CrossRef]

17. Naus, J.; van Vliet, B.J.M.; Hendriksen, A. Households as change agents in a Dutch smart energy transition: On power, privacy and participation. Energy Res. Soc. Sci. 2015, 9, 125-136. [CrossRef]

18. Mauger, R. The voluminous energy transition legal framework in France and the question of its recognition as a branch of law, Energy Policy 2018, 122, 499-505. Energy Policy 2018, 122, 499-505. [CrossRef]

19. Weiss, O.; Pareschi, G.; Georges, G.; Boulouchos, K. The Swiss energy transition: Policies to address the Energy Trilemma. Energy Policy 2021, 148, 111926. [CrossRef]

20. Böhringer, C.; Cantner, U.; Costard, J.; Kramkowski, L.-V.; Gatzen, C.; Pietsch, S. Innovation for the German energy transitionInsights from an expert survey. Energy Policy 2020, 144, 111611. [CrossRef]

21. Li, F.G.N.; Pye, S.; Strachan, N. Regional winners and losers in future UK energy system transitions. Energy Strategy Rev. 2016, 13, 11-31. [CrossRef]

22. Elshurafa, A.M.; Farag, H.M.; Hobbs, D.A. Blind spots in energy transition policy: Case studies from Germany and USA. Energy Rep. 2019, 5, 20-28. [CrossRef]

23. Taghizadeh-Hesary, F.; Rasoulinezhad, E.; Shahbaz, M.; Vo, X.V. How energy transition and power consumption are related in Asian economies with different income levels? Energy 2021, 237, 4578. [CrossRef]

24. Brauers, H.; Oei, P.-Y.; Walk, P. Comparing coal phase-out pathways: The United Kingdom's and Germany's diverging transitions. Environ. Innov. Soc. Transit. 2020, 37, 238-253. [CrossRef]

25. Geels, F.W. Technological transitions as evolutionary reconfiguration process: A multi-level perspective and a case-study. Res. Policy 2002, 31, 1257-1274. [CrossRef]

26. Geels, F. Multi-level perspective on system innovation: Relevance for industrial transformation. In Understanding Industrial Transformation: Views from Different Disciplines; Olsthoorn, X., Wieczorek, A.J., Eds.; Springer: Dordrecht, Holland, 2006. 
27. Rotmans, J.; Kemp, R.; van Asselt, M. More evolution than revolution: Transition management in public policy. Foresight 2001, 3, 15-31. [CrossRef]

28. Rijnsoever van, F.J.; Leendertse, J.A. Practical tool for analyzing socio-technical transitions. Environ. Innov. Soc. Transit. 2020, 37, 225-237. [CrossRef]

29. Hajer, M. Authoritative Governance: Policy Making in the Age of Mediatization; Oxford University Press: Oxford, UK, 2009 ; pp. 56-58.

30. Yuana, S.L.; Sengers, F.; Boon, W.; Hajer, M.A.; Raven, R. A dramaturgy of critical moments in transition: Understanding the dynamics of conflict in socio-political change. Environ. Innov. Soc. Transit. 2019, 37, 156-170. [CrossRef]

31. Bosman, R.; Loorbach, D.; Frantzeskaki, N.; Pistorius, T. Discursive regime dynamics in the Dutch energy transition. Environ. Innov. Soc. Transit. 2014, 13, 45-59. [CrossRef]

32. Geels, F. Regime Resistance against Low-Carbon Transitions: Introducing Politics and Power into the Multi-Level Perspective. TheoryCult. Soc. 2014, 31, 21-40. [CrossRef]

33. Lee, D.; Hess, D.J. Incumbent resistance and the solar transition: Changing opportunity structures and framing strategies. Environ. Innov. Soc. Transit. 2019, 33, 183-195. [CrossRef]

34. Roberts, J.C.D. Discursive destabilisation of socio-technical regimes: Negative storylines and the discursive vulnerability of historical American railroads. Energy Res. Soc. Sci. 2017, 31, 86-99. [CrossRef]

35. Verloo, N. Negotiating urban conflict: Conflicts as opportunity for urban democracy. Ph.D. Thesis, Amsterdam Institute for Social Science Research, Amsterdam, The Netherlands, 2015.

36. Hess, D.J. Coalitions, framing, and the politics of energy transitions: Local democracy and community choice in California. Energy Res. Soc. Sci. 2019, 50, 38-50. [CrossRef]

37. Geels, F. The multi-level perspective on sustainability transitions: Responses to seven criticisms. Environ. Innov. Soc. Transit. 2011, 1, 24-40. [CrossRef]

38. Fairclough, N. Language and Power; Longman Group: New York, NY, USA, 1989.

39. Mautner, G. Discourse and Managament. Critical Perspectives Through the Language Lens; Macmillan Education Palgrave: London, UK, 2016.

40. Phillips, N.; Hardy, C. Discourse Analysis. Investigating Processes of Social Construction; Sage Publications Inc.: London, UK; New Dehli, India, 2002.

41. Meyer, M. Between theory, method and politics: Positioning of the approaches to CDA. In Methods of Critical Discourse Analysis; Meyer, M., Wodak, R., Eds.; Sage Publications Ltd.: London, UK, 2001; pp. 14-32.

42. Fairclough, N.; Duszak, A. Wstęp: Krytyczna analiza dyskursu-Nowy obszar badawczy. In Krytyczna Analiza Dyskursu. Interdyscyplinarne Podejście do Komunikacji Społecznej; Duszak, A., Fairclough, N., Eds.; Towarzystwo Autorów i Wydawców Prac Naukowych UNIVERSITAS: Kraków, Polland, 2008; pp. 10-23.

43. Fairclough, N. Critical discourse analysis in transdisciplinary research. In A New Agenda in (Critical) Discourse Analysis: Theory, Methodology and Interdisciplinarity; Wodak, P., Ed.; John Benjamins: Amsterdam, The Netherlands, 2005; pp. 53-70.

44. Kuchler, M.; Bridge, G. Down the black hole: Sustaining national socio-technical imaginaries of coal in Poland. Energy Res. Soc. Sci. 2018, 41, 136-147. [CrossRef]

45. Baran, J.; Szpor, A.; Witajewski-Baltvilks, J. Low-carbon transition in a coal-producing country: A labour market perspective. Energy Policy 2020, 147, 111878. [CrossRef]

46. Żuk, P.; Szulecki, K. Unpacking the right-populist threat to climate action: Poland's pro-governmental media on energy transition and climate change. Energy Res. Soc. Sci. 2020, 66, 101485. [CrossRef]

47. Tarasova, E. (Non-) Alternative energy transitions: Examining neoliberal rationality in official nuclear energy discourses of Russia and Poland. Energy Res. Soc. Sci. 2018, 41, 128-135. [CrossRef]

48. Aruga, K.; Bolt, T.; Pest, P. Energy Policy trade-offs in Poland: A Best-worst scaling discrete choice experiment. Energy Policy 2021, 156, 112465. [CrossRef]

49. Vasev, N. Governing energy while neglecting health-The case of Poland. Health Policy 2017, 121, 1147-1153. [CrossRef]

50. Reisigl, M.; Wodak, R. The discourse-historical approach. In Methods of Critical Discourse Analysis; Meyer, M., Wodak, R., Eds.; Sage: London, UK; New Dehli, India; Singapore, 2001; pp. 23-60.

51. Kopińska, V. Edukacja Obywatelska w Szkole. Krytyczna Analiza Dyskursu Podręczników Szkolnych; Toruń, Wydawnictwo Naukowe Uniwersytetu Mikołaja Kopernika: Toruń, Polland, 2017; pp. 154-160.

52. De Cilia, R.; Reisigl, M.; Wodak, R. The Discursive Construction of National Identities. Discourse Soc. 1999, 10, 149-173. [CrossRef]

53. Mautner, G. Analiza gazet, czasopism i innych mediów drukowanych. In Jakościowa Analiza Dyskursu w Naukach Społecznych; Wodak, R., Krzyżanowski, M., Eds.; Oficyna Wydawnicza: Warszawa, Poland, 2011; pp. 50-85.

54. Reisigl, M.; Wodak, R.; Cillia, R. The Discursive Construction of National Identities. Discourse and Discrimination. Rhetorics of Racism and Anti-Semitism; Routledge: London, UK, 2001.

55. EURACOAL Statistics 2020, Coal and Lignite Production and Imports in Europe. Available online: https:/ / euracoal.eu/info/ euracoal-eu-statistics/ (accessed on 21 May 2021).

56. GUS 2020, Główny Urząd Statystyczny. Available online: https:/ /stat.gov.pl/obszary-tematyczne/srodowisko-energia / energia / zuzycie-paliw-i-nosnikow-energii-w-2019-roku,6,14.html (accessed on 21 April 2021).

57. Górnictwo. Barbórka—4 Grudnia. 2016. Available online: https:/ / stat.gov.pl (accessed on 3 May 2021). 
58. Frankowski, J.; Mazurkiewicz, J.; Sokołowski, J.; Lewandowski, P. Zatrudnienie w górnictwie węgla kamiennego w Zagłębiu Górnosląskim. IBS Res. Raport 2020, 1, 1-39.

59. Biuletyn Statystyczny nr 3/2021. Available online: https://stat.gov.pl/obszary-tematyczne/inne-opracowania/informacje-osytuacji-spoleczno-gospodarczej/biuletyn-statystyczny-nr-32021,4,110.html (accessed on 21 May 2021).

60. Kasztelewicz, Z. Blaski i cienie górnictwa węglowego w Polsce. Polityka Energetyczna 2012, 15, 7-27.

61. Szpor, A.; Ziółkowska, K. The Transformation of the Polish Coal Sector; GSI Report; International Institute for Sustainable Development: Winnipeg, MB, Canada, 2018.

62. Kaczorowski, P.; Gajewski, P. Paweł Górnictwo węgla kamiennego w Polsce w okresie transformacji. Acta Univ. Lodz. Folia Oeconomica 2008, 219, 201-227.

63. Józef, D.; Marian, T. Górnictwo, górnictwo. I co dalej? What after mining? Przegląd Górniczy 2017, 73, 1-12.

64. Brauers, H.; Oei, P.-Y. The political economy of coal in Poland: Drivers and barriers for a shift away from fossil fuels. Energy Policy 2020, 144, 111621. [CrossRef]

65. Nowaczyk, P. Możliwości udzielania pomocy publicznej dla sektora węlowego w Unii Europejskiej na przykładzie Polskiej Grupy Górniczej sp. z o.o. Przegląd Górniczy 2016, 72, 48-53.

66. Derski, B.; Zasuń, R. Ogromna Strata Górnictwa, Choć Węgiel Najdroższy w Historii, Wysokienapięcie.pl. 2020. Available online: https:// wysokienapiecie.pl/27457-ogromna-strata-gornictwa-choc-wegiel-mamy-najdrozszy-w-historii/ (accessed on 15 May 2021).

67. Instytut Jagielloński Kantar Public Stan Polskiego Górnictwa Według Górników, ich Partnerów i Otoczenia Społecznego. Raport z Badania, Warszawa, Poland 2021. Available online: https://jagiellonski.pl/news/846/badanie_gornicy_niechetni_zmianom_ na_slasku (accessed on 4 May 2021).

68. Idzikowski, A.; Cierpicki, T. Economy and energy analysis in the operation of renewable energy installations-A case study. Prod. Energy Arch. 2021, 27, 90-99.

69. Androniceanu, A. Social responsibility, an essential strategic option for a sustainable development in the field of bio-economy. Amfiteatru Econ. 2019, 21, 503-519. [CrossRef]

70. Popp, J.; Kovács, S.; Oláh, J.; Divéki, Z.; Balázs, E. Bioeconomy: Biomass and biomass-based energy supply and demand. New Biotechnol. 2021, 60, 76-84. [CrossRef]

71. UN Climate Change Newsroom. Historic Paris Agreement on Climate Change. 195 Nations Set Path to Keep Temperature Rise Well Below 2 Degrees Celsius, United Nations Framework Convention on Climate Change. 12 December 2015. Available online: http:/ / newsroom.unfccc.int/unfccc-newsroom/finale-cop21/, (accessed on 14 April 2021).

72. Elias, S.A. Climate Change and Energy. In Encyclopedia of the Anthropocene; Dellasala, D., Michael, I., Goldstein, M.I., Eds.; Elsevier: Amsterdam, The Netherlands, 2018; Volume 1, pp. 457-466.

73. Yang, M.; Sandu, S.; Li, W.; Khalid, M.T. Renewable energy in Australia: A wider policy discourse. Chin. J. Popul. Resour. Environ. 2019, 17, 241-253. [CrossRef]

74. Zawada, M.; Pabian, A.; Bylok, F.; Cichobłaziński, L. Innowacje w sektorze energetycznym. Zesz. Nauk. Politech. Częstochowskiej. Zarzadzanie 2015, 19, 7-21.

75. Seroka-Stolka, O.; Gajda, J. Zarządzanie środowiskowe według normy ISO $14001 \mathrm{w}$ przedsiębiorstwach górnictwa węgla kamiennego-wybrane aspekty. Gospod. W Prakt. I Teor. 2015, 2, 5-20. [CrossRef]

76. Androniceanu, A.; Popescu, C.R. An inclusive model for an effective development of the renewable energies public sector. Adm. Si Manag. Public 2017, 28, 81-96.

77. IEA 2017, Energy Technology Perspectives 2017. Available online: https://www.iea.org/data-and-statistics/data-product/ energy-technology-perspectives-2017-2 (accessed on 17 May 2021).

78. Wall, W.P.; Khalid, B.; Urbański, M.; Kot, M. Factors influencing consumer's adoption of renewable energy. Energies 2021, 14, 5420. [CrossRef]

79. Grondys, K.; Androniceanu, A.; Dacko-Pikiewicz, Z. Energy management in the operation of enterprises in the light of the applicable provisions of the energy efficiency directive (2012/27/EU). Energies 2020, 13, 4338. [CrossRef]

80. Androniceanu, A.-M.; Căplescu, R.D.; Tvaronavičienè, M.; Dobrin, C. The interdependencies between economic growth, energy consumption and pollution in Europe. Energies 2021, 14, 2577. [CrossRef]

81. Akerboom, S.; Botzen, W.; Buijze, A.; Michels, A.; Rijswick, M. Meeting goals of sustainability policy: CO2 emission reduction, cost effectivness and social acceptance. An analysis of the proposal to phase-out coal in the Netherlands. Energy Policy 2020, 138, 111210. [CrossRef]

82. Kämmerlings, R. Gefährliche Nostalgie. Wider die Romantisierung der Kohle. Die Welt, 2018. Available online: https:/ /www. welt.de/kultur/plus185720950/Gefaehrliche-Nostalgie-Wider-die-Romantisierung-der-Kohle.html (accessed on 4 May 2021).

83. Ganowski, S.; Rowlands, I.H. Read all about it! Comparing media discourse on energy storage in Canada and the United Kingdom in a transition era. Energy Res. Soc. Sci. 2020, 70, 101709. [CrossRef]

84. Brand, U.; Niedermoser, M.K. The role of trade unions in social-ecological transformation: Overcoming the impasse of the current growth model and the imperial mode living. J. Clean. Prod. 2019, 225, 173-180. [CrossRef] 